\title{
Kaboom! Volcano Hazards Mitigation as Government Information
}

\author{
Ben Chiewphasa
}

Preparation for an imminent volcanic eruption relies on strategic communication between experts and the general public, ongoing scientific research and monitoring, and government assistance. Should one falter, lives are at stake at the most critical moment, whether it involves inescapable pyroclastic flows or perhaps plane engine shutdown from volcanic ash. Throughout history, legislative concerns surrounding volcano hazards have been built around the notion of proactiveness, yet financial and resource support oftentimes reflect a tendency towards reactiveness. The following document examines the legislative evolution of volcano hazards mitigation that has extended its reach well into 2020. In addition, an overview of the United States Geological Survey's Volcano Hazards will be followed by an evaluation of government databases for finding historic and current volcanic data and information.

$E$ xploring volcanic hazards mitigation through a government information lens corresponds with taking a hard look at relationships between multifaceted stakeholders. Hazards produced during volcanic eruptions such as lahars (a violent mudflow or debris flow mixed in with pyroclastic material) and airborne ash are not concerned with political boundaries and commonly transcend dividing lines on a global scale. The 2010 eruption of Iceland's Eyjafjallajökull volcano, for example, savagely impacted air travel by closing a large airspace in Europe during April $15-21$, resulting in more than 100,000 cancelled flights that affected 7 million passengers. ${ }^{1}$ Unsurprisingly, volcano hazards mitigation is oftentimes an international effort, providing a rich array of international documents and data. For example, volcanic ash advisory messaging is produced by nine Volcanic Ash Advisor Centers stationed in eight countries. ${ }^{2}$ Different countries also have different philosophies on how to handle and mitigate volcanic risk. Some nations put volcanologists at the forefront of decision-making, whereas the United States relies on the United
States Geological Survey (USGS) for providing up-to-date alerts and statuses, keeping the public informed, but also delivering invaluable data to government stakeholders for further action.

Prepping for volcanic eruptions and anticipating or mitigating volcanic risks is not a straightforward feat. Attempts to reduce risk can cause consequential disruption in our society, such as evacuating densely populated urban sprawls, or allowing people to return to their homes when "the coast is clear"or so it seems. Planning for volcanic hazards is tasked not only by expert volcanologists, but also by governmental representatives and public officials who oftentimes make the final call; a decision that could be a matter of life, death, or long-term tarnishing of credibility and public trust, especially for those vigilant about scientific accuracy.

According to the 2018 National Volcanic Threat Assessment by the USGS, eighteen volcanoes in the United States are listed in the "very high threat" category and thirty-nine were listed as "high threat." The risks certainly exist and although governmentfunded research has persisted for many decades, legislation that attempts to modernize and financially support volcano monitoring and hazards mitigation programs generally gain traction only when catastrophic or significant eruptions unfold. The following document will first examine the history of volcano hazards mitigation within United States legislation, provide an overview of the Volcano Hazards Program (a key entity in hazards assessment and monitoring-both nationally and internationally), ${ }^{4}$ and will review access to volcano data captured, produced, and made available through USGS, NOAA (National Oceanic and Atmospheric Administration), and international affiliates.

\section{Legislative Snapshot of Disaster Relief}

Since volcanic disaster mitigation falls under the umbrella of natural hazards policies and legislation, it is important to 
understand how the federal government handles and interprets the concept of disaster relief. The time between 1803 and 1950 saw the rise of 128 separate laws that handled disaster relief in a very siloed and cumbersome manner. In hindsight, there was no single comprehensive legislation that streamlined disaster relief-Congress had to pass separate laws to provide federal funding for each major and sporadic disaster. To offset inefficiencies, Congress would end up passing the Federal Disaster Relief Act (Public Law 81-875) in 1950, authorizing the President to provide supplementary federal assistance via state governors' requests after the declaration of major disasters. The act ultimately helped streamline disaster relief but its other intent was to "supplement the efforts and available resources of the State and local governments." Essentially, the federal government was solely designated as a supporting entity for state and local governments rather than being placed in the frontlines-an issue linked to congressional debates on disaster relief rationalization. On one hand, natural disasters can be interpreted as unforeseen acts of Mother Nature. Realistically, natural disasters consist of complex interactions between the economic, social, and natural world; rather than interpret natural disasters in this light, Congress instead viewed natural disasters solely as unpredictable acts of nature. This interpretation justified the underfunding of the Presidential Disaster Relief Fund during the 1970's because budgeting for the unpredictable was deemed an impossible undertaking. ${ }^{6}$ Legislation regarding disaster relief was brought into the forefront of public interest via the Disaster Relief Act of 1974 (Public Law 93-288), a bill introduced on February 26, 1974 by Senator Quentin Burdick. Many agencies had their hands tied in disaster relief, so the act attempted to unify the great cause by establishing "a program of disaster preparedness that utilizes services at all appropriate agencies (including the Defense Civil Preparedness Agency)" and also states that "the President shall insure that all appropriate federal agencies are prepared to issue warnings of disasters to State and Local officials."

\section{Volcano Hazards Legislation}

The Federal Disaster Relief Act of 1974 is considered to be monumental for its role in hazards mitigation as it relates to volcanic eruptions; the Director of the USGS had been assigned the responsibility to issue disaster warnings "for an earthquake, volcanic eruption, landslide, or other geologic catastrophe" (1974 Disaster Relief Act 42 U.S.C. 5201 et seq.). ${ }^{8}$ The act had maintained a two-part orientation linked to a 1950 statute (later to have been superseded by the 1974 legislation): (1) federal assistance is meant to supplement state and local recovery efforts and relief; (2) federal assistance is enacted through presidential declaration only after a gubernatorial request was made.' In 1988, the Robert T. Stafford Disaster Relief and Emergency Assistance Act (Stafford Act) would amend the Disaster Relief Act of 1974, authorizing the President to directly issue major disaster declarations and enabling federal agencies to assist local and state government overwhelmed by large-scale catastrophes. ${ }^{10}$ Declarations are issued only after the occurrence of natural catastrophes as defined by 42 U.S.C. 5122(2): "including any hurricane, tornado, storm, high water, wind-driven water, tidal wave, tsunami, earthquake, volcanic eruption, landslide, mudslide, snowstorm, or drought" or "regardless of cause, [after a] fire, flood or explosion."11 The Stafford Act amendments were largely driven by hurricane disasters rather than volcanoes-in particular, the wake of Hurricane Katrina in August 2005 raised concerns and questions on how the government ultimately handled the historic tragedy. Via the Post-Katrina Emergency Management Reform Act of 2006 and the Security and Accountability for Every Port Act of 2005 (SAFE Port Act), Congress expanded the pre-disaster authority of the Federal Emergency Management Agency (FEMA) to ensure future effectiveness of disaster preparedness. ${ }^{12}$

Talks of modernizing and enhancing volcano early detection and monitoring protocols and systems began to take shape in the 111th Congress. Introduced by Senators Lisa Murkowski and Mark Begich on April 2, 2009, the National Volcano Early Warning and Monitoring Systems Act (S.782) was largely a response to the end of supplemental funding ( $\$ 2.7$ million per year from fiscal year 1996 through fiscal year 2008) for volcano monitoring dictated by the Federal Aviation Administration (FAA). ${ }^{13}$ Funding cuts to volcano monitoring coincidentally aligned with 2007's expiration of FAA's tax structure at the time; this gave room for the fiscal year 2008 President's budget to propose a restructuring of FAA's financing system that puts greater emphasis on aviation user fees instead of excise taxes. ${ }^{14}$ Also coincidental was FAA's five-year budget plan (fiscal year 2008 through fiscal year 2012) for the National Airspace System, highlighting zero dollar allocation in volcano monitoring for fiscal year 2009-onward. Amid looming financial overhauls, FAA's reprioritization of projects and investments appeared to have left little space for volcano hazards monitoring and mitigation. ${ }^{15}$ However, due to the very real threats of volcanoes to aviation, Senate bill 782 would go on to garner the support of the Committee on Energy and Natural Resources, but would fail to gain any further traction. ${ }^{16}$ In hindsight, the bill attempted to establish a USGS-based program tasked with monitoring and studying volcanic activity as a form of pre-disaster assessment. Also important was the S.782's noble intent "to warn and protect people and property from undue and avoidable harm 
from volcanic activity." ${ }^{17}$ The bill was later reintroduced as S.566 in the 112 th Congress. ${ }^{18}$ Through a statement on introduced bills and joint resolutions on March 14, 2011, volcanic hazards detection was deemed critical for freight and passenger aircraft safety due to the urgency of over thirty active volcanoes in Alaska. ${ }^{19}$ The act would end up losing traction yet again and reemerge as S.2056 in the 114th Congress in alignment with growing advocacy and support from the Department of the Interior. Each iteration of the National Volcano Early Warning and Monitoring System (NVEWMS) Act evolved to focus on the USGS' National Volcano Early Warning System (NVEWS), a blueprint for updating existing monitoring networks to ensure that all active volcanoes in the United States and Territories are monitored appropriately. ${ }^{20}$

Hawaii's Kīlauea would unleash an impressive torrent of ash that flew more than 30,000 feet in the air in the morning of May 17, 2018. ${ }^{21}$ For the next couple of months which felt like an eternity to Hawaiian locals, series of endless eruptions would mercilessly destroy over 700 homes up through August. ${ }^{22}$ Coincidentally, Senate lawmakers had convened the same day as the initial eruption to vote on the 115th Congressional iteration of the NVEWMS Act and passed the bill via unanimous consent. The bill was eventually consolidated into larger legislation: The John D. Dingell, Jr. Conservation, Management, and Recreation Act (S.47). Unlike past versions of the NVEWMS, S.47 would swiftly pass through Congress and get signed into law (Public Law 116-9) by President Donald J. Trump on March 12, 2019. ${ }^{23}$ Five bills later-introduced in nearly every congressional session by Senator Murkowski-an early warning detection protocol and system is in place. Fifty-five million dollars are to be distributed over fiscal years 2019 through 2023 in order for USGS to strategically implement and sustainably support NVEWS. ${ }^{24}$ The System's intent is to modernize, organize, unify (into a single system), and standardize the monitoring systems already in place which include the Alaska Volcano Observatory, Cascades Volcano Observatory, Yellowstone Volcano Observatory, California Volcano Observatory, and Hawaiian Volcano Observatory. Funding will also be allocated towards a grants program that supports research in volcano monitoring technology and science. ${ }^{25}$

It is important to remember that the timely rise of NVEWS is not indicative of the dawn of volcano hazards mitigation in our government. Rather, NVEWS is part of a greater initiative involving volcano safety-a complex and intricate system encompassing multiple agencies beyond the USGS including the Centers for Disease Control and Prevention (CDC), Department of Homeland Security (DHS), FAA, and NOAA. NVEWS itself falls under the USGS' Volcano Hazards Program umbrella.

\section{Volcano Hazards Program}

Federal funding for studies related to active volcanoes was established in 1924 and primarily focused on understanding Hawaii's Killauea and Mauna Loa volcanoes. Consequently, the USGS' Hawaiian Volcano Observatory (HVO) acted as the epicenter for advances in volcano monitoring techniques, technology, and best practices from the 1920's through the 1970's. ${ }^{26}$ HVO's acclaim was made possible by its early research commitments to volcano hazards mitigation and its close proximities to active volcanoes, resulting in valuable lessons learned. ${ }^{27}$ Today, the HVO's mission largely expanded to the Volcano Hazards Program (VHP) whose mission is to "lessen the harmful impacts of volcanic activity by monitoring active and potentially active volcanoes, assessing their hazards, responding to volcanic crises, and conducting research on how volcanoes work." ${ }^{28}$ It was largely the Robert T. Stafford Disaster Relief and Emergency Assistance Act that solidified VHP's role, mission, and emphasis on volcano hazards mitigation. Modern VHP functions can be traced to the May 18, 1980 Mount St. Helens eruption, as the data collected from this unanticipated event - through monitoring and describing the eruption-provided an invaluable wealth of knowledge. The Mount St. Helens' eruption also led to an increase in funding for the VHP alongside the establishment of Washington's Cascades Volcano Observatory (CVO). ${ }^{29}$ VHP's increased funding in reaction to catastrophe eerily mirrors the underlying rationale for Congress supporting the NVEWMS Act-via its integration with the John D. Dingell Jr. Conservation, Management, and Recreation Act-recently in 2019. ${ }^{30}$

\section{Volcano Disaster Assistance Program}

The infamous catalyst for an international volcano crisis management initiative under the VHP umbrella, otherwise known as the Volcano Disaster Assistance Program (VDAP), can be traced to the calamitous mudflow triggered by the Nevado del Ruiz eruption in Armero, Colombia. ${ }^{31}$ Geologists stationed near Nevado del Ruiz in November 1984 monitored increasing levels of seismic activity, with earthquakes up to magnitude four. The events that transpired on the night of November 13, 1985 would be horrific-Nevado del Ruiz erupted and ejected $3.5 \times 10^{10}$ kilograms of tephra (ejected volcanic particles), triggering a mudflow that would devastate the city of Armero and kill more than 25,000 civilians in the surrounding area. ${ }^{32}$ What made this incident particularly tragic was how it all could have been avoided. The Colombian government had received multiple warnings and sound advice by multiple volcanological organizations but decided not to evacuate the area despite the suspicious levels of volcanic activity detected two months prior to the eruption. ${ }^{33}$ 
A more streamlined system of communication between government officials and volcanologists could have been more conducive for warnings that get properly interpreted and acted upon in a timely manner. ${ }^{34}$ At the end of the day, a proper warning did not reach the people of Armero in time. The tremendous death toll yielded a new respect for volcanic sites all over the world, especially those that are prone to lahars as a result of hot pyroclastic flows initiated by the rapid melting of ice and snow. ${ }^{35}$ On December 11, 1985, President Ronald Reagan would sign “a joint resolution reaffirming the friendship of the people of the United States with the people of Colombia following the devastating volcanic eruption of November 13, 1985." ${ }^{36}$ What eventually resulted was the establishment of the VDAP, a well-equipped professional team composed of volcanologists and hydrologists who respond to requests made by foreign officials and governments asking for scientific and technical assistance during volcanic crises. VDAP scientists have provided their services in Latin America, southwest Pacific, Africa, and Alaska. ${ }^{37}$ In particular, the VDAP have responded to over seventy major volcanic crisis at more than fifty volcanoes worldwide, strengthening their response capacity in at least twelve counties since $1986 .{ }^{38}$

\section{Finding Current VHP Data and Information}

Today, data collected by the VHP is invaluable for assisting scientists in interpreting volcanic behavior, forecasting imminent eruptions, and identifying community impacts—all of which help reduce volcanic risks. ${ }^{39}$ Information regarding the current activity levels of volcanoes monitored by the VHP is made freely available through the US Volcanoes and Current Activity Alerts. ${ }^{40}$ Their website's homepage emphasizes an interactive map and easily-navigable interface where users can filter and find active volcanoes based on region (i.e., CA-NV, Mariana Islands, ID-WY, etc.), status (i.e., "Elevated," "Normal," etc.), or activity alerts (i.e., notices for aviation, current messaging from the Volcano Notification Service, etc.). Users can closely monitor specific volcanoes by navigating to specific Volcano Pages. Alaskan volcano data and information is managed by the Alaska Volcano Observatory, whereas other volcanoes fall within the greater VHP authority.

Alert levels made visible on the US Volcanoes and Current Activity Alerts have a variety of colors and terminology, depicting ranked levels of concern. Different colors are used to inform the aviation sector about airborne hazards, whereas ranked terms are meant to inform people on the ground about volcano statuses. ${ }^{41}$ According to the USGS, ground-based volcano alert levels and aviation specific color codes commonly move up or down in conjunction with one another (i.e., "Watch" term with an orange color, "Warning" term with a red color, etc.). ${ }^{42}$
There are also alternative ways to obtain VHP-produced volcano alert notifications beyond their interactive map. VHP issues different types of notifications that reflect specific information needs, ranging from Volcano Activity Notices (messaging related to significant volcanic activity such as airborne ash, lahars, lava flows, etc.), status reports, and scheduled updates churned on a daily, weekly, or monthly basis. ${ }^{43}$ These notifications are made publicly available through their website, social media outlets, and the USGS Volcano Notification Service, an email subscription service. ${ }^{44}$ Users wanting to look up past volcano updates can search in their archive. ${ }^{45}$

\section{NOAA's Government Data and Information}

Beyond USGS and VHP, NOAA also assimilates and archives volcano data that supports mitigation, research, response, and planning. The Volcano Location Database, for example, houses over 1,500 volcanoes where users can search on a variety of parameters ranging from geography, volcanoes' morphology/ type, time or eruption, and more. ${ }^{46}$ Alternatively, their "Significant Volcanic Eruption Database" lists over 500 volcanoes that are considered to be "significant" if they fulfill at least one of the following criteria: "caused fatalities, caused moderate damage (approximately one million dollars or more), with a Volcanic Explosivity Index (VEI) of 6 or larger, caused a tsunami, or was associated with a major earthquake. ${ }^{\prime 47}$ The Significant Volcanic Eruption Database has similar advanced search parameters as the Volcano Location Database, but there are more options such as filtering by damage in millions of dollars, number of deaths, and whether or not the volcano was associated with a tsunami or earthquake. Users are also able to download data as tab-delimited files for further data analysis, manipulation, and visualization. NOAA's Natural Hazards Interactive Map is another worthwhile resource to explore as it provides users with an interactive map similar to the USGS VHP's US Volcanoes and Current Activity Alerts; unlike that map, however, NOAA's encompasses volcanoes from all over the world. $^{48}$

Various international government agencies alongside NOAA provide worldwide coverage of Volcanic Ash Advisories (VAA). Nine Volcanic Ash Advisory Centers (VAAC) were created throughout the world in response to the International Civil Aviation Organization's (ICAO) call for a system that keeps aviators informed of volcanic hazards. The NOAA Satellite and Information Service manages a portal to all nine VAAC offices' VAA messages. ${ }^{49}$ NOAA also oversees the Volcanic Ash Advisory Database that houses legacy VAA messages issued by the Washington VAAC, encompassing a broad spectrum of information ranging from pilot reports, reports composed by 


\section{Chiewphasa}

volcanic observatories, surface weather observations, satellite imagery, and content produced by news media outlets. ${ }^{50}$

\section{Conclusion}

Recent national and international emergencies, brought to the forefront of news/media outlets and government officials, are firm reminders of the destructive and erratic nature of volcanoes. The resurgence of both federal and international support for volcano hazards mitigation is, therefore, reassuring. In fact, a technical background paper for the United Nation's Office for Disaster Risk Reduction proudly mention open access journals and reports as catalysts for the sharing of knowledge-specifically, knowledge derived from episodic emergencies; this is critical to an effective and global progression towards reducing volcanic disaster risk. ${ }^{51}$ The difficulty of forecasting eruptions, coupled with economic and community impacts (oftentimes across national boundaries), make volcanic hazards a worthwhile example when exploring the complexities of government information dissemination.

Ben Chiewphasa (ben.chiewphasa@umontana.edu), Government Information Librarian Maureen and Mike Mansfield Library, University of Montana

\section{References}

1. "Aviation: Eyjafjallajökull Impact," Volcanic Ashfall Impacts Working Group, https://volcanoes.usgs.gov /volcanic_ash.

2. "Volcanic Ash Advisory Centers," Office of Satellite and Product Operations, NOAA, https://www.ssd.noaa.gov /VAAC/vaac.html.

3. John W. Ewert, Angela K. Diefenbach, and David W. Ramsey, 2018 update to the U.S. Geological Survey national volcanic threat assessment. US Geological Survey Scientific Investigations Report, no. 2018-5140 (Reston, VA: US Geological Survey, 2018): 8-11, https://doi .org/10.3133/sir20185140.

4. "U.S. Volcanoes and Current Activity Alerts," Volcano Hazards Program, https://volcanoes.usgs.gov.

5. Federal Citizen Information Center, $A$ Citizen's Guide to Disaster Assistance (Washington, DC: Federal Emergency Management Agency, 2003).

6. Ted Steinberg, Acts of God: The Unnatural History of Natural Disaster in America (New York: Oxford University Press, 2006): 176.
7. Disaster Relief Act of 1974, 88 Stat. 143 (1974), https:// www.hsdl.org/?abstract\&did=458661.

8. Elliott C. Spiker and Paula L. Gori, National Landslide Hazards Mitigation Strategy-A Framework for Loss Reduction. US Geological Survey Circular, no. 1244 (Reston, VA: US Geological Survey, 2003), 1, https://pubs .usgs.gov/circ/c1244/index.html; Federal Disaster Relief Act of 1950, 64 Stat. 1109 (1950).

9. Francis X. McCarthy, Federal Stafford Act Disaster Assistance: Presidential Declarations, Eligible Activities, and Funding, CRS Report, no. RL33053 (Washington, DC: Congressional Research Service, 2011): 10, https://fas .org/sgp/crs/homesec/RL33053.pdf.

10. McCarthy, 3.

11. Robert T. Stafford Disaster Relief and Emergency Assistance Act, 42 U.S.C. $\$$ 5122(2) (1988), https://www.loc .gov/item/uscode1988-016042068/.

12. McCarthy, 3.

13. National Volcano Early Warning and Monitoring Program Act, S.782, 111th Cong. (2009), https://www .govinfo.gov/content/pkg/BILLS-111s782is/pdf/BILLS -111s782is.pdf; House Committee on Appropriations, Subcommittee on Interior, Environment, and Related Agencies. Interior, Environment, and Related Agencies Appropriations for 2012, 112th Cong., 1st sess., March 17, 2011, https://www.govinfo.gov/content/pkg /CHRG-112hhrg66897/pdf/CHRG-112hhrg66897 .pdf; Committee on Energy and Natural Resources, $\mathrm{Na}$ tional Volcano Early Warning and Monitoring System Act, 111th Congress 2nd sess., 2010, S. Rept. 133, https:// www.congress.gov/congressional-report/111th-congress /senate-report/133/1.

14. Office of Management and Budget, Budget of the United States Government, Fiscal Year 2008 (Washington, DC: Government Printing Office, 2007): 108, https://www .govinfo.gov/app/details/BUDGET-2008-BUD.

15. Federal Aviation Administration, National Airspace System Capital Investment Plan, FY 2008-2012 (Washington, D.C: Federal Aviation Administration, 2008): 60, https://www.faa.gov/air_traffic/publications/cip/files /CIP_08-12.pdf.

16. Committee on Energy and Natural Resources, National Volcano Early Warning and Monitoring System Act, 111th Congress 2nd sess., 2010, S. Rept. 133, https:// www.congress.gov/congressional-report/111th-congress /senate-report/133/1.

17. Committee on Energy and Natural Resources, 9. 
18. To Provide for the Establishment of the National Volcano Early Warning and Monitoring System, S.566, 112th Cong. (2011), https://www.govinfo.gov/content/pkg/BIL LS-112s566is/pdf/BILLS-112s566is.pdf.

19. Senator Murkowski, speaking on S. 566, 112th Cong., 1st sess., Congressional Record 157 (March 14, 2011): S 1602.

20. "Statement for the Record Before the Senate Committee on Energy and Natural Resources Regarding S. 2056, the National Volcano Early Warning and Monitoring System Act, September 22, 2016, Washington DC," US Department of the Interior, https://www.doi.gov/ocl/s-2056.

21. US Geological Survey, "UPDATE, 5/17/18, 10:40am HST," Kïlauea Volcano Erupts (blog), News, May 17, 2018, https://www.usgs.gov/news/k-lauea-volcano-erupts.

22. "Recovery of Hawai' i Volcanoes National Park," National Park Service, https://www.nps.gov/havo/recovery.htm.

23. John D. Dingell, Jr. Conservation, Management and Recreation Act, 133 Stat. 580 (2019), https://www.con gress.gov/116/plaws/publ9/PLAW-116publ9.pdf.

24. "National Volcano Early Warning System-Monitoring Volcanoes According to Their Threat," Volcano Hazards Program, https://volcanoes.usgs.gov/vhp/nvews.html.

25. John D. Dingell, Jr. Conservation, Management and Recreation Act, 133 Stat. 580 (2019), https://www.con gress.gov/116/plaws/publ9/PLAW-116publ9.pdf.

26. National Research Council, Review of the U.S. Geological Survey's Volcano Hazards Program (Washington, DC: The National Academies Press, 2000): 16, https://doi .org/10.17226/9884; "Hawaiian Volcano Observatory (HVO)," Volcano Hazards Program, https://volcanoes .usgs.gov/observatories/hvo.

27. National Research Council, 19.

28. National Research Council, 16.

29. National Research Council, 20.

30. National Volcano Early Warning and Monitoring System Act, S.346, 115th Cong. (2018), https://www.con gress.gov/115/bills/s346/BILLS-115s346es.pdf; National Volcano Early Warning and Monitoring System Act, H.R.4475, 115th Cong. (2018), https://www.congress .gov/115/bills/hr4475/BILLS-115hr4475rh.pdf; John D. Dingell, Jr. Conservation, Management and Recreation Act, 133 Stat. 580 (2019), https://www.congress.gov/116 /plaws/publ9/PLAW-116publ9.pdf.

31. "Volcano Disaster Assistance Program," Volcano Hazards program, https://volcanoes.usgs.gov/vdap.

32. "VDAP Brings Nations Together in Volcanic Crisis Management and Response," Volcano Disaster Assistance
Program, https://volcanoes.usgs.gov/vdap/about.html; J. L. Naranjo, H. Sigurdsson, S. N. Carey, and W. Fritz (1986). "Eruption of the Nevado del Ruiz Volcano, Colombia, on 13 November 1985: Tephra Fall and Lahars," Science 233, no. 4767 (Aug. 29, 1986): 961-963.

33. L. Jaramillo, A Rivera, G. Duque, A. César, A. Solano, M. Hall, and D. Herd, "September 1985 (SEAN 10:09): Phreatic activity and strong seismicity decline in October," Nevado del Ruiz: Bulletin Reports-Index, September 1985, https://volcano.si.edu/volcano.cfm?vn=351020.

34. Jacob B. Lowenstern and David W. Ramset, The Volcano Disaster Assistance Program-Helping to Save Lives Worldwide for More Than 30 Years. US Geological Survey Fact Sheet, no. 2017-3071 (Reston, VA: US Geological Survey, 2017): 4, https://doi.org/10.3133/fs20173071.

35. "Nevado del Ruiz, Colombia: Lahars," Susan McLean and Patricia Lockridge, https://www.ngdc.noaa.gov/haz ard/stratoguide/nevadofeat.html.

36. Joint Resolution Reaffirming the Friendship of the People of the United States with the People of Colombia Following the Devastating Volcanic Eruption of November 13, 1985, 99 Stat. 1033 (1985).

37. National Research Council, 21.

38. Lowenstern and Ramset, 1.

39. "About the Volcano Hazards Program," Volcano Hazards program, https://volcanoes.usgs.gov/vhp/about.html.

40. "U.S. Volcanoes and Current Activity Alerts," Volcano Hazards Program, https://volcanoes.usgs.gov.

41. "Volcanic Alert-Levels Characterize Conditions at U.S. Volcanoes," Volcano Hazards Program, https://volca noes.usgs.gov/vhp/about_alerts.html.

42. "Alert Level Icons Depict Volcano Status on Interactive Maps," Volcano Hazards Program, https://volcanoes .usgs.gov/vhp/alert_icons.html.

43. "Volcano Notifications Deliver Situational Information," Volcano Hazards Program, https://volcanoes.usgs.gov /vhp/notifications.html.

44. "Volcano Notification Service (VNS)," US Geological Survey, https://volcanoes.usgs.gov/vns2.

45. "Search the Volcano Updates Archive," Volcano Hazards Program, https://volcanoes.usgs.gov/vhp/archive_search .html.

46. "Volcano Location Database Search," Smithsonian Institution Global Volcanism Program, https://ngdc.noaa .gov/nndc/struts/form?t=102557\&s=5\&d=5.

47. "National Geophysical Data Center / World Data Service (NGDC/WDS): Significant Volcanic Eruptions 


\section{Chiewphasa}

Database," National Geophysical Data Center, NOAA, https://doi.org/10.7289/V5JW8BSH.

48. "Natural Hazards Viewer," National Centers for Environmental Information, https://maps.ngdc.noaa.gov/viewers /hazards.

49. "Volcanic Ash Advisory Centers," Office of Satellite and Product Operations, NOAA, https://www.ssd.noaa.gov /VAAC/vaac.html.

50. "Volcanic Ash Advisory Database," National Centers for Environmental Information, NOAA, https://ngdc.noaa .gov/nndc/servlet $/$ ShowDatasets?dataset=101597\&sear ch_look=39\&display_look=39.

51. S. K. Brown et al., Global Volcanic Hazards and Risk: Technical Background Paper for the Global Assessment Report on Disaster Risk Reduction 2015 (Global Volcano Model and the International Association of Volcanology and Chemistry of the Earth's Interior, 2015): 66, https:// www.preventionweb.net/english/hyogo/gar/2015/en/bg docs/GVM,\%202014b.pdf. 